Yuliia Opanasiuk,

Ph.D., Associate Professor, Sumy State University, Ukraine

iD $h$ ttps://orcid.org/0000-0002-9236-8587

email:yu.opanasuk@management.sumdu.edu.ua

Monika Grabowska,

Ph.D., Wroslaw University of Economics and Business, Poland

iD ORCID ID, 0000-0001-9627-0221

email: monika.grabowska@ue.wroc.pl

Olena Volovyk,

Sumy State University, Ukraine

email: lero85@meta.ua

Correspondence author: yu.opanasuk@management.sumdu.edu.ua

\title{
METHODOLOGY FOR STAFF MANAGEMENT ASSESSMENT EFFICIENCY IN THE MEDICAL INSTITUTIONS
}

Abstract. This paper considers human resources to be important for the effective functioning and development of the organization in current socio-economic conditions. Corporate management involves the impact on people (corporate staff) primarily.

The authors noted that the staff management assessment is a powerful instrument to increase the management process's effectiveness. The normative documents of the Ministry of Health of Ukraine define the following methods of quality control of medical services: clinical audit and monitoring. The purpose of a clinical audit is to find opportunities to achieve high-quality health care. Continuous tracking of staff provides an opportunity to make effective management decisions and increase productivity. An adequate system for assessing the quality of medical staff should respond not only to the result of medical care but also to prevent defects. Personnel management in health care quality should be carried out to avoid mistakes in the provision of medical care. This concept is designed to create an internal structural quality management system. Therefore, it is essential to understand the assessment process and its interactions at different stages of the management process within the organization. In the paper, the authors determined ways to enhance the medical staff management assessment. The study presents the essence and features of medical staff assessment based on the general principles and methods for assessing the effectiveness of public and private medical institutions. The authors analyzed the medical staff assessment system in medical institutions and identified its features under medical reform. Besides, the study provided the investigation of the current state of the staff assessment of medical institutions. It analyzed the areas of concern in the methods and mechanisms of staff assessment. To investigate the current situation in the medical institution, the structure and movement of medical staff were analyzed. The findings identified the gaps in the current staff assessment system and the reasons for the low rates of nursing staff. The authors highlighted ways to improve the current staff assessment system in the institution through the social satisfaction criterion, interviewing the parturient women and configuration management of quality based on the PDCA cycle. The obtained results showed that the medical institution had different reserves available to increase the parturient women satisfaction with the level of medical services received.

Keywords: staff management, performance evaluation, medical staff efficiency, social satisfaction criterion, clinical audit, monitoring.

Introduction. The quality of medical care is a common problem of medical and preventive treatment institutions. It worth emphasizing that it inevitably evolve into a national problem of life quality. Besides, the modernization of the Ukrainian health care system provokes the urgency for improving the nurses' work assessment as an important part of the medical staff resources. The nurses' performance

Cite as: Opanasiuk, Yu., Grabovska, M., \& Volovyk, O. (2021). Methodology for Staff Management Assessment Efficiency in the Medical Institutions. Health Economics and Management Review, 1, 89-99. http://doi.org/10.21272/hem.2021.1-09

89

Received: 24 January 2021 
significantly contributes to the quality of public medical services. Moreover, it facilitates the development and implementation of objective criteria for evaluating their work and its compliance with state standards.

There are many different methods of evaluating staff, but most of them have common shortcomings the subjectivity of the expert's decision maker and personal choice for receiving expert decisions. These assessment methods do not consider the specifics of the work of medical staff and cannot be used without adjustment.

This study's purpose is to form a methodology for medical staff quality assessment. The study's subject is the relation that comes out of medical staff quality assessment. The study's object is the quality assessment of nursing staff.

Literature Review. Systematization of scientific background showed that medical care quality assessment is the most popular in hospital practice. In turn, a pool of researchers devoted their studies (Donabedian, 2005; Sitash, 2012; Machuga, 2012) to investigate the issues of medical care quality. Notably, the scientist Sitash (2012) believed that medical care quality is a process of interaction between doctor and patient conditioned the ability to perform medical technology; reduce the risk of progress or new disease rise; use resources rationally; and ensure patient satisfaction.

On the other hand, Yerzhak (2016) investigated the characteristics of the medical care quality on investors (the state). The author defined medical care quality as the rational use of available material resources of health care facilities, which fulfil the world standards of medical resources.

In the studies (Mikhailovskaya, 2020; Yerzhak, 2016), the authors believed that medical care quality greatly considers the concept of medical care as «a set of therapeutic and preventive measures carried out by certain technologies to achieve a positive specific outcome». In the paper Vashchenko (2014), the principles of personnel management were considered.

Kryachkova et al. (2019) believe that medical staff's evaluation by comparing individual performance indicators with external goals is needed. This is standard practice in many healthcare systems. The authors propose using methods of variation statistics to assess the performance of medical staff during the transformation of the health care system.

Derlyuk and Reha (2017) consider the quality of nursing care and identify the main criteria by which to evaluate the work of nurses. The authors believe that expert evaluation of the work of medical staff is an essential element in characterizing the quality of medical care.

In Grynko and Savchenko (2017) the author considers the main methods of assessing human resources as follows: formal approaches (questionnaires and testing) and informal approaches (interview and observation).

Wang et al. (2017) developed a scale for evaluating medical staff, which includes patient research and public opinion

Despite there are many different ways to evaluate staff, most of them have common disadvantages such as the subjectivity of the decision-maker, the set of used methods, and the personal choice of the expert to obtain expert decisions.

Methodology and research methods. In this paper, the authors formulated the following hypothesis: it is essential to consider both objective and subjective characteristics (such as customer feedback) in assessing the quality of nurses performance.

The study involved the sociological methods on the quality of nurses performance in the neonatal care departments to assess the parturient women satisfaction with the quality of medical care and staff satisfaction with their work. The authors used the sociological survey results and data from patients and parturient women questionnairing from 15 August to 15 October 2020.

Results. Staff management assessment is a powerful instrument for improving the management process effectiveness. It stands to mention that personnel management's functioning should be systematically assessed to accumulate experience and gain data. Besides, that will measure the costs and benefits of implementing a general personnel management program. The accumulated knowledge and data allow a comparative analysis of the current organization effectiveness with the previous periods. 
Therefore, the organization of quality analytical work is an important factor. In the study Khodykina (2015), the author noted that it is necessary to define clear terms, periodicity and persons responsible for the statical database maintenance of assessment results.

The effectiveness of personnel management in the organization is determined by the extent of used performance potential for achieving the goals. However, in this case, it is difficult to assess the manager's performance work and productivity. Therefore, to provide a comprehensive assessment of the managers' productivity, it is essential to consider the psychological qualities as an element of comprehensive assessment often used worldwide (Pashchenko, 2012).

Figure 1 demonstrates the current most used methods to evaluate the manager performance. Notably, these methods are objective. They allow formalizing data and systematizing results. Moreover, it is possible to compare the parameters based on the assessment results where applicable (Stalinska, 2015).

\begin{tabular}{l|l|l}
\multicolumn{1}{|c}{ Quantitative methods } & \multicolumn{1}{c}{ Qualitative methods } & \multicolumn{1}{c}{ Combined method } \\
\hline $\begin{array}{l}\text { - point rating method; } \\
\text { - method of defining the }\end{array}$ & - oral or written performance & - method of incentive \\
\hline coefficients; & assessment; & assessment; \\
- rank method; & - model matching method; & - stuff grouping method; \\
- method of paired & matrixand biographic & \\
$\quad$ comparisons; & methods; & \\
- formating of a graphic & - group discussion method. \\
manager profile; & & \\
- experimental method. &
\end{tabular}

Figure 1. Methods of managers work assessment

Sources: developed by the authors based on (Stalinska, 2015).

For determining the effectiveness of the personnel management system, certain criteria and indicators are used. Herewith, when choosing assessment criteria, it is important to understand the final goal of using the assessment results. Besides, it is worth focusing on the assessed categories of employees. In the personnel management system, the effectiveness criterion can be defined by implementing the established norms of production (planned norms) or service quality. Furthermore, it will be appropriate to consider the reduced turnover of the workforce, or unreasonable costs due to time-out, etc.

It stands to mention that foreign companies have vast experience in personnel management. Besides, they have their own assessment systems. Notably, the personnel management assessment, included in the general system, has certain features. In addition to the main factors that are important in assessing productivity in the United States, there are the following:

- $\quad$ the nature of the tasks performed by the employee. Ther is necessary to think that the tasks of officer and manager deserve a higher rating than the tasks of the employee;

- $\quad$ state requirements, restrictions and legislation;

- $\quad$ personal attitude of the estimator to the employee. Thus, if the estimator moral values coincide with the work ethic, his assessment could be adequate. Otherwise, the assessment could cause an increase in layoffs, refusals to raising in rank, reducing employee productivity;

- $\quad$ own work style of the leader: to ensure punishment or rewarding, the leader could apply the received estimation honestly or dishonestly. Therefore, the results of the work assessment could deeply vary from assumed by organizers;

- $\quad$ the trade unions in the organization: could both support and oppose the staff assessment system. 
The importance of criteria depends on the tasks requiring the assessment results. Therefore, if the main goal is to increase labour productivity, then the criteria of labour productivity are used. If the goal is to promote employees, there is a need for other criteria that characterize the potential performance in the work position.

The findings showed that in most US companies, monthly employee assessment is commonplace. Besides, most US companies use the method of the graphical rating scale. Besides, they often use descriptive methods, mainly as a component of a graphic rating scale. On the other hand, a variety of questionnaires are popular among a vast amount of companies. Other methods account for only $5 \%$. To evaluate the performance of managers and employees who do not participate in the production process (with customer service), the management method by objectives is used (Bazaliyska., 2015).

On the other hand, personnel management in Japanese companies is mainly based on respect for tradition. Thus, there is group collectivism and the motivation to collaborate. It stands to emphasize that subordination to an older leader is quite popular in Japanese companies. The superiors are also older than the junior in age, while their length of service is bigger. Employees are very committed to the company ideals, while their relationships with subordinates and ordinary employees are informal. The big companies could recruiter staff for lifelong, while the staff rotation period regarding professions and positions is 3-5 years.

To provide staff assessment, Japanese companies study the employees' biographies and personal data thoroughly. For direct assessment, they use the methods of proficiency tests as writing projects, reports, etc. The most common Japanese methods of assessing the work quality of employees include oral interviews, interviews and group discussions. In parallel with mentioned above, questionnaires of employees are used to identify individual abilities, personality development and identify suggestions and proposals to management (Prokhorchuk and Mukhina, 2014).

Nowadays, there are many ways to assess staff performance. However, there is no unique classification and typology of personnel assessment methods. Herewith, the information reliability of staff assessment is achieved through the use of various complementary evaluation methods. Notably, the more methods involved, the more comprehensively and deeply evaluated the employee (Opanasyuk and Rud, 2012). Figure 2 shows the multicriteria classification of personnel assessment methods.

In the medical institution practice, there are five most commonly used methods for assessing the amount and quality of medical care. The medical and preventive treatment institutions (MPTI) use them depending on the assessment purpose, objects and temporal characteristics (Order of the Ministry of Health № 752, 12).

1. Statistical method - to generalize information about the amount and quality of medical care using whole or sample accounting to assess all management system stages:

- $\quad$ resources (personnel, financing, material and technical support, justification of resource need);

- $\quad$ scope of work;

- $\quad$ correspondence of medical and technological process to standards applied;

- $\quad$ outcome and effectiveness of single processes and institution-wide.

2. Expert evaluation method - to consider patients' personal characteristics, atypical situations, and other factors that affect the quality of the medical services. In this case, the expert evaluation is conducted by experts who received special training, have experience and have analytical techniques. It stands to note that licensing and accreditation commissions, MPTI workers, experts of insurance companies widely use the expert evaluation method.

3. Medical and economic method - using economic information and the results of expert assessments to provide quality control of insurance companies and territorial funds of compulsory health insurance $(\mathrm{CHI})$.

4. Social method is used to assess the patients' satisfaction with medical care quality and staff satisfaction. There are several methods to assess the patient's satisfaction:

- interview; 
- $\quad$ reviews in feedback book;

- questionnaire.

5. Integrated method - includes a combination of the methods mentioned above. In commonly, only a comprehensive quality assessment of the medical services could provide the necessary feedback to implement a quality assurance system. In the process of assessing health care quality, it is necessary to define the quality. Notably, the quality of the health care system largely determines the level of health and quality of life. Therefore, the concept of medical care quality is one of priority in health care (Karamishev, 2007).

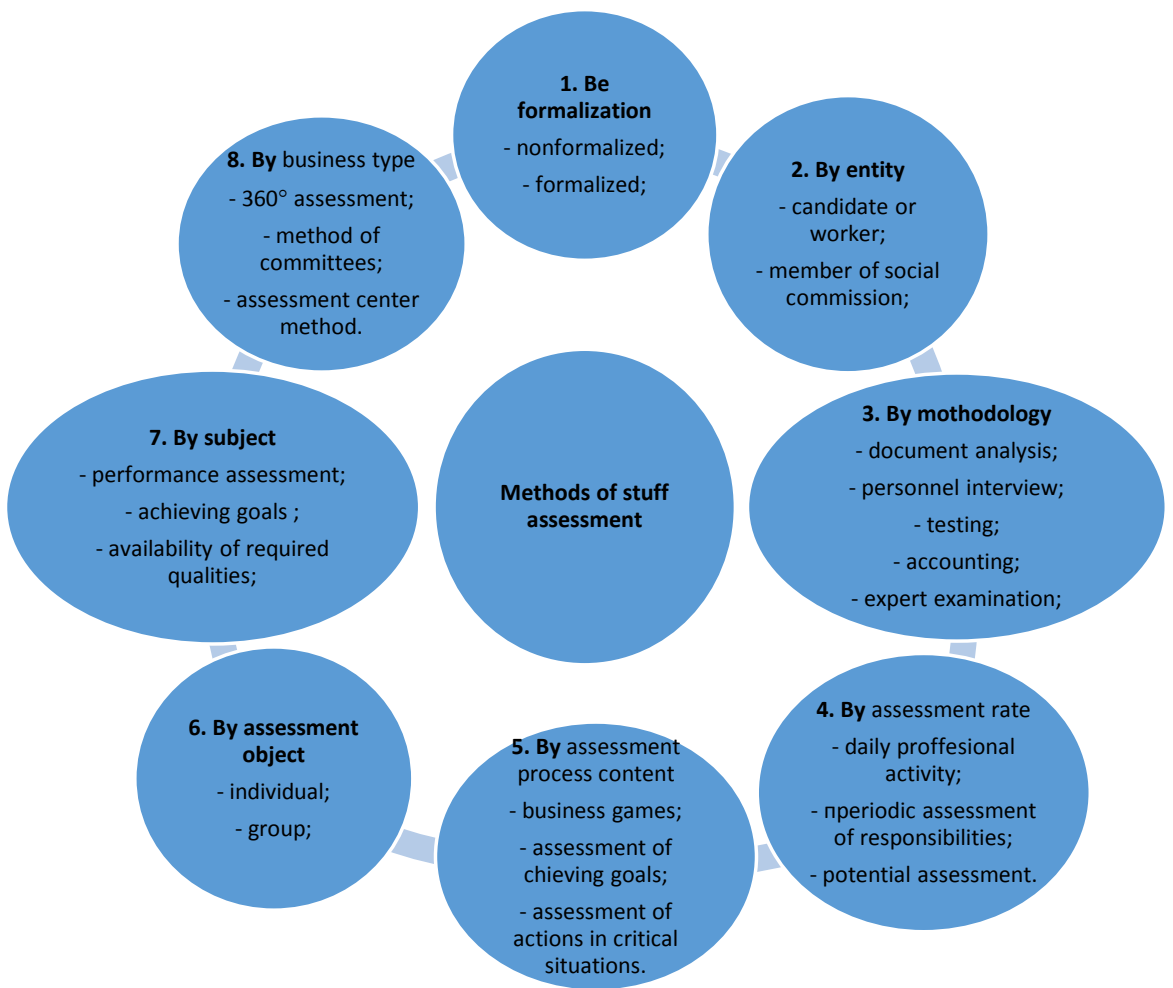

Figure 2. The multicriteria classification of stuff assessment methods

Sources: developed by the authors based on (Doskuch, 2021).

The principal features (components) of medical care quality are as follows (Table 1):

outcome - external medical efficiency, which shows the organization goals achievement, the ratio of the achieved result of medical activities to the maximum possible based on the latest advances in science and technology, i.e. the relationship between actual effect and ideally possible maximum;

- $\quad$ economic effectiveness - internal medical efficiency, which measures the rational use of resources, i.e. the minimal cost of medical aid without losing the quality;

- $\quad$ optimality - the balance between health care costs and the results obtained from improving the public health;

- $\quad$ adequateness - satisfying public demand in medical services;

- $\quad$ acceptability - compliance of the provided medical care with the patients' expectations;

- $\quad$ legitimacy - compliance of the ethical principles, laws, regulations, rules; 

Institutions

- $\quad$ fairness - reasonable and legal distribution of medical care and benefits among the population;

- $\quad$ inheritance - the degree of coordinating compliance and ensuring the necessary influence providing medical care;

health care;

scientific and technical level - the level of using current scientific and technological knowledge

- $\quad$ accessibility - access to various medical aid services;

- $\quad$ timeliness of medical care delivery.

The consideration of the normative documents of the Ministry of Health of Ukraine showed the quality control methods of medical services, such as clinical audit and monitoring. It is worth noting that the clinical audit in a public medical treatment facility should be conducted quarterly to find opportunities to achieve high-quality health care (European Information, 2021). In turn, the specialized medical care system aims to improve the medical care of patients and parturient women. Besides, it is a scientifically grounded and targeted way to solve the staffing problem. This study provided a survey on satisfaction with the working conditions of nurses in maternity hospitals. The findings showed that, in general, nurses are dissatisfied with the managers' attitude, inclusive of senior nurses. However, this reason isn't common for all departments to change the workplace. Thus, most employees are dissatisfied with the duty scheme and high-intensity work.

Table 1. Features of medical care quality

\begin{tabular}{|c|c|c|}
\hline $\begin{array}{c}\text { Component of the medical care } \\
\text { process }\end{array}$ & Characterized object & Tasks \\
\hline Medical care & $\begin{array}{c}\text { Knowledge, skills and experience of } \\
\text { medical staff }\end{array}$ & $\begin{array}{c}\text { Hands-on assistance to the } \\
\text { patient }\end{array}$ \\
\hline $\begin{array}{l}\text { Conditions for medical care } \\
\text { delivery }\end{array}$ & Working conditions & $\begin{array}{l}\text { Effective work conditions } \\
\text { arranging for particular workers }\end{array}$ \\
\hline Initial patient's condition & Object of interaction & $\begin{array}{l}\text { Developing the general principles } \\
\text { for the arrangement of work in } \\
\text { medical institutions }\end{array}$ \\
\hline
\end{tabular}

Sources: developed by the authors based on (Mikhailovskaya, 2020, Boychuk, 2017).

In this study, to assess the work quality of nurses, the objective criteria were investigated following expert charts and subjective criteria. The research involved data obtained from the interview and survey questionnaire of patients and parturient women from 15 August to 15 October 2020. Besides, the assessment of the work quality was provided based on the criteria developed separately for the hospitalization and hospital discharge of parturient women; the Council of Senior Nurses (experts) recommendations; the universal coefficient calculated monthly by the senior nurse of the department.

The main expert criteria for calculating the Integral Quality Criterion is as follows: K1 - nurse training; K2 - arrangement of nurse work; K3 - nursing practice; K4 - the emergency of medical support; K5 medical ethics and deontology; K6 - infectious safety; K7 - documentation of nursing activities (Fig.3).

The following formula is used to calculate the integral performance criterion:

$$
\mathrm{I} P C=\frac{K 1+K 2+K 3+K 4+K 5+K 6+K 7}{7}
$$

The study sample consists of nurses under 30 years $-10 \%$, nurses of retirement age, including $30 \%$ of nurses over 30 years and $60 \%$ of nurses over 55 years.

Figure 4 demonstrates the average monthly integrated performance criterion according to the expert cards of the nurses of the neonatal care department. It stands to note that the principal disadvantage of the assessment system of nurses effectiveness at neonatal care department is ignoring the social satisfaction criterion (SRC) of parturient women. Thus, analysis of the quality of nurse work and the work 
Yu., Opanasiuk, M., Grabovska, O., Volovyk. Methodology for Staff Management Assessment Efficiency in the Medical Institutions

of the neonatal department as a whole didn't consider the indicators and results of the social survey. However, SRC could significantly affect the final score of each nurse in the long perspective.

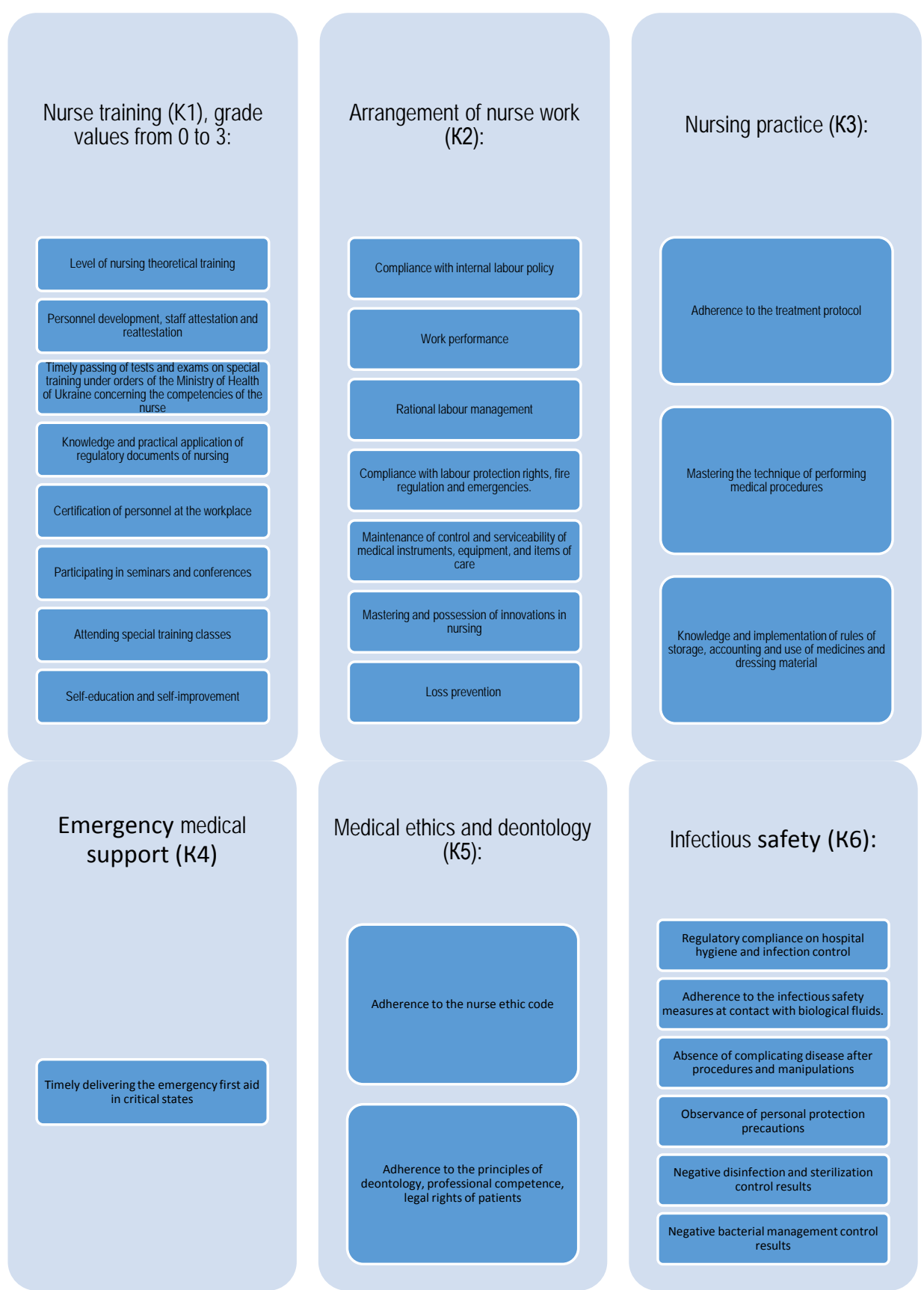

Figure 3. Assessment criteria of work performance of nurses of neonatal care department Sources: developed by the authors based on (Yaremko and Ryabkova, 2017). 
Yu., Opanasiuk, M., Grabovska, O., Volovyk. Methodology for Staff Management Assessment Efficiency in the Medical Institutions

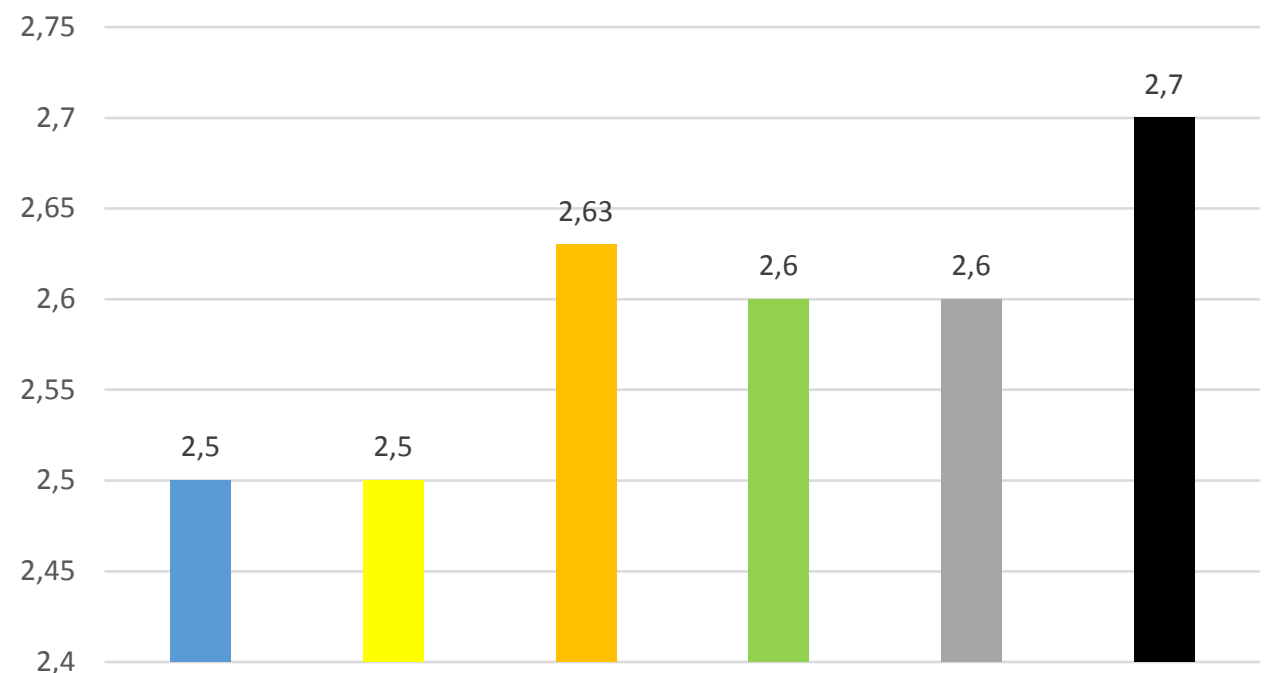

Figure 4. Average monthly integral performance criterion by expert cards of nurses of neonatal

Sources: developed by the authors.

The second stage of this survey provided the questionnaire nurses of the neonatal department to measure their motivation and the existing problems. In general, nurses are dissatisfied with the managers' attitude, inclusive of senior nurses. But this reason isn't common for all departments to change the workplace. Thus, most employees are dissatisfied with the duty scheme and high-intensity work.

In the study, the sociological methods to assess the satisfaction of parturient women with the medical care quality and staff satisfaction with their work. For assessing the parturient women satisfaction, their reviews in the feedback book were analyzed. Moreover, the study involved a survey of 10 parturient women per month from July to October 2020. The survey and questionnaire results of each parturient women about her nurse were evaluated based on a 3-point scale. Each month, 10 different parturient women filled out a questionnaire. Then, the rating points were summed up to calculate the average monthly score.

Notably, previously, the calculation of IPC didn't consider the average score of the subjective quality assessment of the nurse work of the neonatal care department. In turn, IPC is a component of the «Final score of nurse work quality compliance to medical care delivery».

Thus, the previous assessment systems considered only subjective negative indicators (complaints). Therefore, it decreased the «Final compliance score», which affected the reduction in the percentage of payments from the material incentive fund. It stands to note that any criterion didn't include the social satisfaction criterion of parturient women with the quality of nurse work. In turn, it considered only the fact of dissatisfaction with the service quality.

The obtained rating points of parturient women were added to $\mathrm{K} 5$ «Criterion of work quality of nurses of neonatal care department» (Fig. 3). Then, the «Final compliance score» was recalculated. Therefore, the nurse work quality score by the subjective assessment affected the «Final compliance score».

The assessment results by the expert cards indicated that the parturient women evaluate both nurses' performance job and the nurse's attitude to parturient women and newborns. 
The results of this survey showed a higher final compliance score in most of the evaluated nurses. Therefore, that has a positive effect on the percentage of payments from the material incentive fund. The study results on integrated performance criterion showed the quantitative satisfaction characteristics of parturient women's with the quality of medical care and qualitative assessments of nurses' work. It allows providing constructive proposals to improve the neonatal care department.

Figure 5 visualizes the comparative analysis of the quality criteria of work with and without questionnaires of parturient women.

Therefore, based on the findings mentioned above, there are several proposals to improve the nurse work assessment at the neonatal care department as follows:

1. Improving the criteria in the «Expert card» considering the detailed quality assessment description criteria and the parturient women satisfaction with the nursing care quality.

2. Developing a plan for monthly monitoring social parturient women's satisfaction with the medical care quality based on the specially designed questionnaires (on the first day of admission and before discharge from the neonatal care department).

3. Creating a work team to prepare the above documents. The work team should consist of the chief nurse of the maternity hospital, chief nurses in the appropriate medical competence from other departments, experienced nurses who are leaders in their departments.

4. Improving the system of postgraduate education regarding ethics, deontology and communication skills. Thus, the communication ability promotes professional success, allowing creating a favourable psycho-emotional of parturient women and increasing their positive mood.

5.

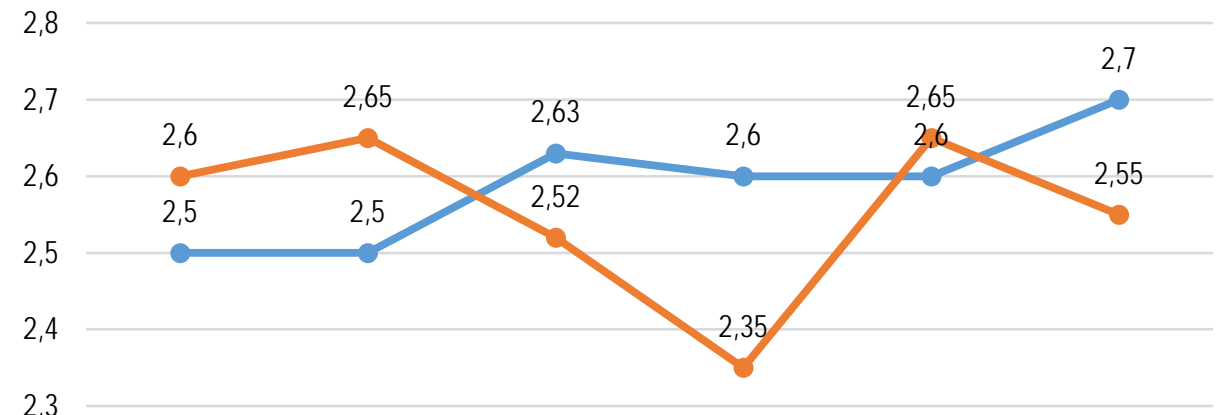

2,2

2,1

$$
\longrightarrow \text { IPC }- \text { SPR }
$$

Figure 5. Comparative analysis of performance criteria with and without considering

Sources: developed by the authors. questionnaire survey of parturient women

Conclusions. The adequate assessment system of medical staff performance quality should consider medical care outcomes and prevent the defects precipitation. Besides, staff management in health care quality should aim to prevent mistakes in medical care delivery. This concept is meant to create an internal structural quality management system.

It stands to emphasize that progressive improvement of medical care quality requires: 
1) developing a strong consumer orientation of services (parturient women);

2) continuously improving all medical processes under the cycle: plan - do - check -act;

3) involving medical staff in the process of work performance quality assessment;

4) highlighting the most important goals in the decision-making process to improve the quality of provided services;

5) increasing the team consciousness on the true motives of their activities;

6) encouraging the free expression of opinions, ideas, and suggestions concerning improving the staff performance quality.

Author Contributions: conceptualization, .Yu. A and O. L.; methodology, O. L. and M. G.; validation Yu. A; formal analysis, Yu. A and O. L.; investigation, Yu. A and O. L.; resources, O. L.; data curation, O. L. and M. G.; writing-original draft preparation, Yu. A.; writing-review and editing, Yu. A.; visualization, Yu. A.; supervision, Yu. A.

Funding: This research received no external funding.

\section{References}

Bazaliyska, N. P. (2015). World experience of staff labor management in countries with developed market economy. Innovative economy, 1, 138-142. Retrieved from [Link] $488 \mathrm{p}$.

Boychuk, Yu. D. (2017).General theory of health and health conservation: a collective monograph. Kharkiv: Ed. Rozhko S.G.

Derlyuk, M. D., \& Reha, N. I. (2017). Assessment of the Quality of Provision of Medical Services by Nursing Personnel in the Conditions of a Private Medical Center. Nursing, 4. [CrossRef]

Donabedian, A. (2005). Evaluating the Quality of Medical Care . Milbank Quartely, 3(4), 691-729. [CrossRef]

Doskuch, L. V. (2012). Methodical approaches to the assessment of personnel of industrial enterprises. Bulletin of the National University «Lviv Polytechnic»: coll. Science. wash. Lviv: Lviv Polytechnic, 91-101. [CrossRef]

European Information and Research Center: website. (2021). Retrieved from [Link]

Grynko T., \& Savchenko, K. (2017.) Scientific and Methodikal Approaches to Personel Potential Estimation at the Medical Institution. Scientific Notes of Ostroh Academy National University, Series «Economics», 7(35). [Google Scholar]

Karamishev, D. V. (2007). Management of the quality of medical care in the context of innovative transformations of the health care system. Chief physician, 8, 68-71. Retrieved from [Link]

Khodykina, I. V. (2015). Approaches to assessing the effectiveness of staff management systems. Scientific Bulletin of Mukachevo State University. Series «Economics»: a collection of scientific papers. Mukachevo: Carpathian Tower, 2(4), Part 2, 115120. Retrieved from [Link]

Kryachkova, L. V., Makhov, I .B., Borvinko, E. V., \& Kozur, O. A. (2019). Application of methods of variation statistics to assess the performance of medical staff. Ukrainian Journal of Medicine, Biology and Sports, 4(20), 171-176. [Google Scholar]

Machuga, N. Z. (2012). Methodological aspects of formation and functioning of the system of quality medical services in Ukraine [Monograph]. Ternopil, Type. 199 p. Retrieved from [Link]

Mikhailovskaya, N. S. (2020). Basic principles of organization of therapeutic care in diseases of internal organs: textbook. Zaporozhye: ZSMU. 213 p. Retrieved from [Link]

Opanasyuk, Yu. A., \& Rud, A. B. (2012). Improving the staff evaluation system at the enterprise. Bulletin of Sumy State University. «Economy» series, 1, 134-140. Retrieved from [Link]

Order of the Ministry of Health № 752 On the procedure for quality control of medical care (of September, 28, 2012). Retrieved from [Link]

Pashchenko, O. I. (2012). Ways to increase the efficiency of management of managers and specialists at the enterprise Development Management, 11, 67-68. Retrieved from [Link]

Prokhorchuk, S. V., \& Mukhina, T. B. (2014). Staff management: foreign. Business Navigator, 2, 208-211. Retrieved from [Link] Sitash, T. D. (2012). Financing of health care system in Ukraine: tendencies and reforming. Mechanism of economic regulation, 1, 164-169. Retrieved from [Link]

Stalinska, A. V. (2015). System of evaluation of staff in the modern industrial enterprise. Agrosvit., 13, 33-36. Retrieved from [Link]

Vashchenko, N. V. (2014.) Adaptation of principles and methods of staff management in the process of enterprise management . Economic Journal XXI, 1-2(1), 98-101. Retrieved from [Link] 

Institutions

Wang, H.,qian, Y., \& Wang, X. I. (2017). Development and Validation Studies of Medical Staff Job Satisfaction Assessment Scale. Chinese Hospital Management,37(3),14-17.

Yaremko, I. Y., \& Ryabkova, O. V. (2014.) Criteria and components of the integrated performance indicator of the enterprise. Lviv Polytechnic National University. Management and entrepreneurship in Ukraine: stages of formation and problems of development. Vol. 797. 423-429. Retrieved from [Link]

Yerzhak, G. Ya. (2016). Healthcare facility management technology: digest. Dnipropetrovsk: DONMB. P.23.

Юлія Опанасюк, к.е.н., Сумський державний університет (Україна);

Моніка Грабовська, Ph.D., Вроилавський університет економіки та бізнесу (Польща);

Олена Воловик, Сумський державний університет, Україна.

Методологічні основи оцінювання ефективності організації роботи персоналу в медичних закладах

у сучасних соціально-економічних умовах одним з важливих ресурсів ефеективного фуннкиіонування і розвитку організації є людські ресурси. Управління будь-якою організацією передбачає насамперед вплив на людей - персонал організації. Потужним важелем для зростання результативності управлінського процесу є оцінювання ефективності управління роботи персоналу. Постійне оцінювання персоналу дає можливість ухвалювати ефрективні управлінські рішення та збільшувати продуктивність праці. Адекватна система оцінювання якості роботи медичного персоналу повинна реагувати не тільки на кінцевий результат медичної допомоги, а й запобігати утворенням дефектів. Управління персоналом у сфері якості медичного обслуговування має здійснюватися з метою запобігання помилок у наданні медичної допомоги. Ця концепція розрахована на створення внутрішньоструктурної системи управління якістю. Для ефективного використання оцінювання персоналу необхідно розуміти, яким иляхом воно здійснюється, як взаємодіє з іншими етапами управлінського процесу в середині організації. У статті розглянуті шляхи поліпшення управління оцінюванням ефектиивності роботи медичного персоналу за рахунок вдосконалення системи управління персоналом закладу охорони здоров'я. Грунтуючись на загальних принципах та методах оцінювання ефрективності роботи працівників державних та недержавних медичних установ, було визначено сутність та особливості оцінювання медичного персоналу. Розглянуто систему оцінювання медичного персоналу в закладах охорони здоров'я, а також особливості оціночного процесу в період запровадження в дію медичної рефформи. Автори дослідили сучасний стан системи оцінювання персоналу медичних установ та проаналізували проблемні моменти у вживаних методах та механізмах оцінювання персоналу. За допомогою аналізу структури та руху медичного персоналу, системи оцінювання працівників, була досліджена поточна ситуація справ у медичній установі. За результатами виявлено недоліки в існуючій системі оцінювання персоналу організації та визначено причини низьких показників сестринського персоналу. Автори висвітлили шляхи вдосконалення існуючої системи оцінювання ефекктивності роботи персоналу в установі за допомогою критерію соціальної задоволеності, методів опитування породіль та організації системи управління якістю на основі циклу РDCA. Отримані результати засвідчили, що в медичній установі існують різні резерви для вдосконалення системи оцінювання персоналу та зростання задоволеності породіль рівнем отримуваних медичних послуд.

Ключові слова: управління персоналом, оцінювання роботи, ефективність роботи медичного персоналу, критерій соціальної задоволеності, клінічний аудит, моніторинг. 